\title{
Reactive oxygen species and male reproductive hormones
}

\author{
Mahsa Darbandi ${ }^{1 \dagger}$, Sara Darbandi ${ }^{1 \dagger}$, Ashok Agarwal $^{2^{*}}$ (D), Pallav Sengupta ${ }^{3}$, Damayanthi Durairajanayagam $^{4}$, \\ Ralf Henkel ${ }^{5}$ and Mohammad Reza Sadeghi ${ }^{6}$
}

\begin{abstract}
Reports of the increasing incidence of male infertility paired with decreasing semen quality have triggered studies on the effects of lifestyle and environmental factors on the male reproductive potential. There are numerous exogenous and endogenous factors that are able to induce excessive production of reactive oxygen species (ROS) beyond that of cellular antioxidant capacity, thus causing oxidative stress. In turn, oxidative stress negatively affects male reproductive functions and may induce infertility either directly or indirectly by affecting the hypothalamus-pituitary-gonadal (HPG) axis and/or disrupting its crosstalk with other hormonal axes. This review discusses the important exogenous and endogenous factors leading to the generation of ROS in different parts of the male reproductive tract. It also highlights the negative impact of oxidative stress on the regulation and cross-talk between the reproductive hormones. It further describes the mechanism of ROS-induced derangement of male reproductive hormonal profiles that could ultimately lead to male infertility. An understanding of the disruptive effects of ROS on male reproductive hormones would encourage further investigations directed towards the prevention of ROS-mediated hormonal imbalances, which in turn could help in the management of male infertility.
\end{abstract}

Keywords: Antioxidants, Hypothalamic-pituitary-gonadal axis, Male infertility, Oxidative stress, Reactive oxygen species, Testosterone

\section{Background}

Over the past 40 years, reports regarding the decline in semen quality [1-4] and its probable consequences on male fertility have encouraged studies about the effects of environment and lifestyle factors on the male reproductive potential. Reactive oxygen species (ROS) produced by exogenous and endogenous factors are highly reactive oxygen derivatives with half-lives in the nanoto milliseconds range. These molecules reportedly play a key role in altering male reproductive functions $[5,6]$. Lifestyle modifications, technological advancements, escalating levels of pollution, alcohol consumption, smoking of cigarettes and vaping, and physical stress are among the prime exogenous causes of ROS production [7-9]. Also, multiple mechanisms involving metabolism in the cell

\footnotetext{
* Correspondence: agarwaa@ccf.org

+Mahsa Darbandi and Sara Darbandi contributed equally to this work.

${ }^{2}$ American Center for Reproductive Medicine, Cleveland Clinic, Cleveland,

Ohio 44195, USA

Full list of author information is available at the end of the article
}

membrane, mitochondria, peroxisomes, and endoplasmic reticulum can produce endogenous ROS [7, 9].

Antioxidants defend against excessive ROS levels through enzymatic (superoxide dismutase, catalases, and peroxidases) and non-enzymatic (vitamins, steroids etc.) mechanisms $[7,10]$. In cases where the imbalance between oxidants (ROS) and antioxidants leans towards the oxidants, oxidative stress (OS) occurs, which puts the cells and the body under stress. As a result, excessive ROS can induce lipid peroxidation, disrupt DNA, RNA as well as protein functions in the spermatozoa and other testicular cells [10].

High ROS levels can increase the possibility of infertility not only directly by inducing OS, but also indirectly by acting through the hypothalamic axes of hormone release [11-13]. ROS reduce male sex hormone levels and disrupt the hormonal balance that regulates male reproductive functions [14], and thus causes infertility. These "endocrine disruptors" not only interfere in the communication between testis and the hypothalamic-pituitary unit, they also disrupt the cross-talk between the 
hypothalamic-pituitary-gonadal (HPG) axis with other hypothalamic hormonal axes $[15,16]$. The testis, as the primary male sex organ, is not only concerned with spermatogenesis, but also with the secretion of several hormones [17] which are required for regulation of gonadotropin secretion, spermatogenesis, formation of male phenotype during sexual differentiation, and normal sexual behaviour [18]. Hence, by interfering with normal hormonal release, ROS disrupt these essential reproductive functions.

Therefore, this review precisely elucidates (a) the role of ROS, generated by various exogenous and endogenous factors, in disrupting hormone secretion by interfering in the endocrine pathways, as well as in their cross-talk, (b) hormonal regulation of the oxidative status of male reproduction, and (c) a possible mechanism of action of ROS-induced disruption of the male reproductive hormonal profile.

\section{Endocrinology of male fertility}

The gonadotropin releasing hormone (GnRH) secreted by the hypothalamus regulates the release and secretion of gonadotropins, luteinizing hormone (LH) and follicle-stimulating hormone (FSH) from anterior pituitary that in turn regulate testicular functions [17]. These gonadal steroids as well as the pituitary gonadotropins, via feedback regulatory mechanisms, further establish physiological homeostasis and maintains normal reproductive functions $[14,17,19]$. FSH receptors are located on the membrane of Sertoli cells, while those of LH are on the Leydig cells. They coordinate to synthesize testosterone, maintain normal spermatogenesis, sperm health and density [19-21].

Moreover, other hormones like estradiol (E2) and prolactin (PRL) also take part in the management of male reproductive function. E2, produced both by the testis and via the peripheral conversion of androgenic precursors, is a potent inhibitor of LH and FSH [18, 19] (Fig. 1). PRL-inhibiting GnRH secretion via modulation of dopaminergic pathway may also reduce $\mathrm{LH}$ and testosterone level and thus is associated with hypogonadism [22]. Dehydroepiandrosterone (DHEA) is another male reproduction ameliorating, steroid hormone secreted by the adrenal cortex $[23,24]$. Inhibin A and B, dimeric hormones produced by Sertoli cells, exhibit negative feedback on FSH secretion and thus also on testicular functions [25]. Moreover, melatonin (MLT), a tryptophan-derived hormone of the pineal gland, positively regulates gonadotropin and testosterone secretion, and thus aid male reproductive functions [26, 27]. Anti-Mullerian hormone $(\mathrm{AMH})$, a dimeric glycoprotein hormone produced in embryonic Sertoli cells, is structurally related to inhibin and is responsible for regression of Mullerian ducts during the first 8 weeks of embryogenesis. It reflects Sertoli cell functions and is inhibited by testosterone under the influence of LH [28-30]. Interactions between the hypothalamo-pituitary-thyroid (HPT) and HPG axes potentially influence testicular development, mostly by the participation of thyroid hormones and FSH [31].

Thus, besides the central control through the HPG axis, the major male reproductive hormones act either individually or via the cross-talks among different endocrine axes to influence male reproductive functions. Consequently, any disruption to these networks may adversely affect male fertility.

\section{Generation of ROS in the male reproductive tract}

Reactive oxygen species (ROS), which are short-lived, unstable, and highly reactive species containing at least one oxygen atom, are able to snatch electrons from other molecules to achieve an electronically-stable state. In this process, the other molecule loses an electron following which a new radical is formed. Subsequently, this radical reacts with another neighbouring molecule, thus passing on the radical status via a reaction called 'radical-chain reaction' until two radicals react with one another forming a stable bond. These reactions amplify the degree of alterations in the cellular structures [32-34].

Human spermatozoa contain abundant mitochondria, particularly in its midpiece [35]. An NADH-dependent oxidoreductase (in the inner mitochondrial membrane) and NAD (P) H-oxidase (in the plasma membrane) are two main sources of superoxide $\left(\mathrm{O}_{2}{ }^{--}\right)[32,33,36]$. The majority of ROS generated in human spermatozoa is $\mathrm{O}_{2}{ }^{\bullet-}$ which is a product of oxidative phosphorylation by addition of an electron to intracellular oxygen and is created between complex I and III of the electron transport chain [37]. $\mathrm{H}_{2} \mathrm{O}_{2}$ is an uncharged, membrane permeable molecule which has been found to be the major initiator of peroxidative damage of the plasma membranes of germ cells [34]. In the presence of transition metals, such as iron $\left(\mathrm{Fe}^{3+}\right)$ and copper, $\mathrm{O}_{2}{ }^{\bullet-}$ and $\mathrm{H}_{2} \mathrm{O}_{2}$ can generate the extremely reactive $\mathrm{OH}^{*}$ through the Haber-Weiss reaction, which consist of a reduction of ferric $\left(\mathrm{Fe}^{3+}\right)$ to ferrous ion $\left(\mathrm{Fe}^{2+}\right)$ [38]. In a subsequent second step, called Fenton reaction, $\mathrm{Fe}^{2+}$ is oxidized by $\mathrm{H}_{2} \mathrm{O}_{2}$ to $\mathrm{Fe}^{3+}$ whereby hydroxide $\left(\mathrm{OH}^{-}\right)$and the most reactive hydroxyl radical $\left(\mathrm{OH}^{*}\right)$ are formed. Furthermore, $\mathrm{O}_{2}{ }^{\bullet-}$ has the ability to interact with nitric oxide (NO) to form peroxynitrite $\left(\mathrm{ONOO}^{-}\right)$, subsequent reactions of which may lead to either apoptotic or necrotic cell death [39]. In the male reproductive tract, ROS finally can be generated by one of these sources according to the above-mentioned mechanisms.

In order to produce the immense amount of energy needed for motility, spermatozoa possess numerous mitochondria in the mid-piece of the flagellum. In the mitochondria, disruption of the membrane potential 


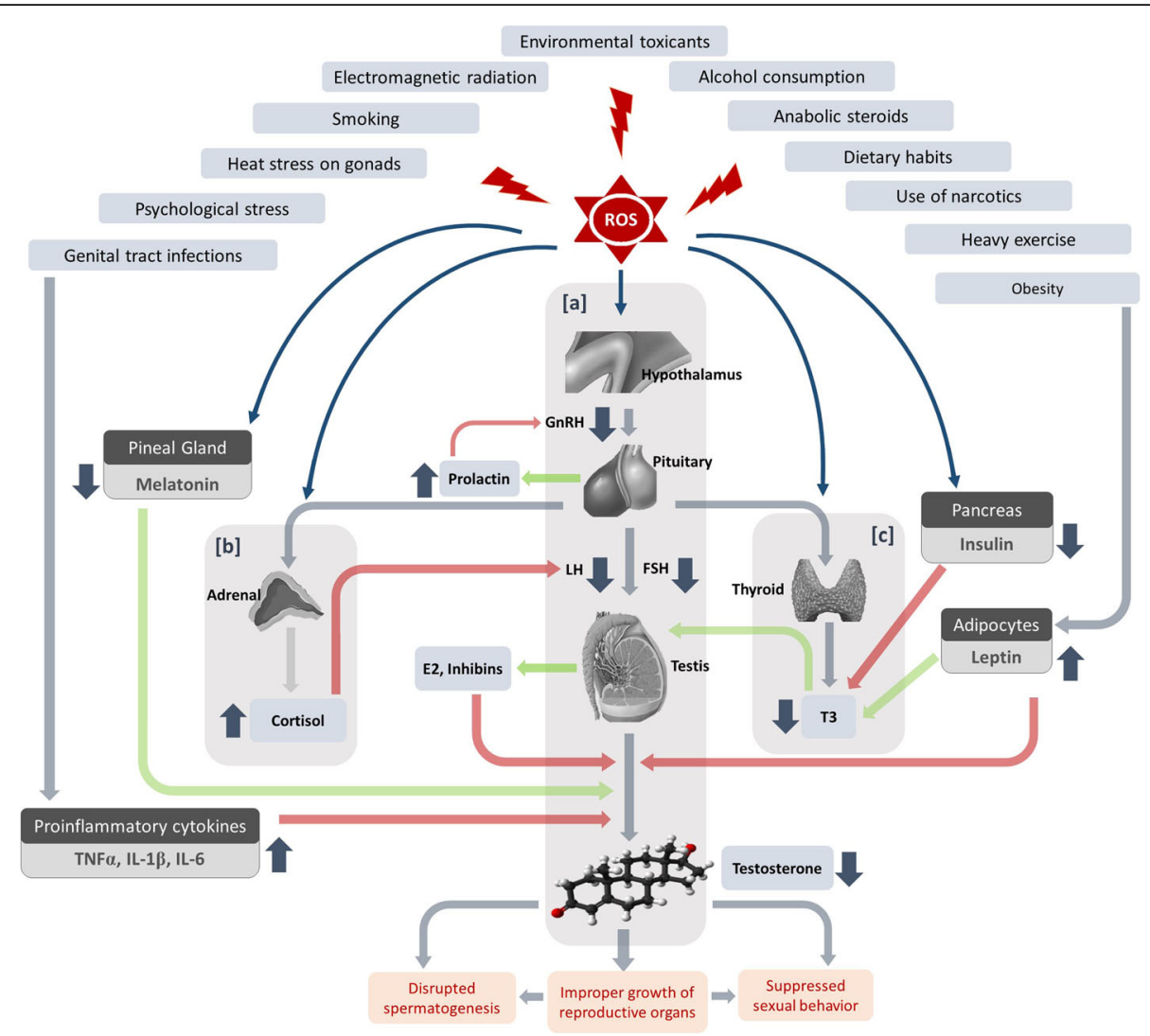

Fig. 1 Sources of reactive oxygen species (ROS) and their impact on the complex endocrine network regulating male reproduction. a High levels of ROS impact upon the HPG axis which results in decreased secretion of male reproductive hormones. $\mathbf{b}$ Through the HPA axis, ROS increases the release of the stress hormone cortisol, which through the HPA-HPG axes cross-talk, further decreases LH secretion. c Elevated ROS also affects the HPT axis which results in decreased T3 production from the thyroid gland, which through the cross-talk between HPT and HPG axes, again decreases testosterone synthesis. ROS also affects the other endocrine glands which interfere with these endocrine axes to result in decreased testosterone production. Increased oxidative stress (OS), in different conditions, decreases insulin production from the pancreas which again reduces T3 production from the thyroid gland and through HPT-HPG axes cross-talk decreases testosterone biosynthesis. ROS production in obesity also increases circulating leptin levels which directly reduces testosterone synthesis in the testis. Reduced melatonin in OS, and increased production of pro-inflammatory cytokines during reproductive tract infections, affects the HPG axis to reduce testosterone biosynthesis. OS also increases prolactin secretion from the anterior pituitary and E2 synthesis from the testis. These two hormones reduce GnRH secretion from the hypothalamus and testosterone biosynthesis from the testis, respectively

leads to electron leakage in the electron transfer chain and subsequently produces ROS. The $\mathrm{Ca}^{2+}$-dependent NADPH oxidase, called NOX5 (encoded by the NOX5 gene) was initially detected in the human testis, but was also found to be present in the acrosomal and mid-piece regions of human spermatozoa [40]. NOX5 is a major generator of ROS and could subsequently induce OS. This enzyme is activated when $\mathrm{Ca}^{2+}$ binds to its cytosolic $\mathrm{N}$-terminal EF-hand and causes conformational changes to the cell through OS [41]. Moreover, during spermatogenesis, the developing spermatozoa extrude their cytoplasm. When spermiogenesis is disrupted and/or excess cytoplasm is not completely extruded (excess residual cytoplasm), the excess cytoplasm will be retained around the mid-piece. Since cytoplasm contains the enzymatic machinery to produce ROS, any hindrance in the elimination of excess cytoplasm would trigger the production of intrinsic amounts of ROS in excess, which, in turn, would lead to oxidative damage of the plasma membrane and sperm DNA [42].

The prostate and seminal vesicles are the major sources of peroxidase-positive leukocytes (polymorphonuclear leukocytes $(50 \sim 60 \%)$ as well as macrophages $(20 \sim 30 \%))$ [43, 44]. Inflammatory responses trigger these cells to generate ROS about 100-times more than it is produced under normal conditions [34, 45, 46]. This elevated ROS production is a part of the natural defense mechanisms of these cells, whereby NADPH-production through the hexose monophosphate shunt is elevated. Leukocyte participation in inflammation is closely connected with the accompanying leukocytospermia [47], a condition defined by the World Health Organization (WHO) as semen samples containing more than one million peroxidase-positive leukocytes per milliliter of 
semen [48]. Varicocele, a condition caused by an abnormal dilation of veins in the pampiniform plexus surrounding the spermatic cord [49], is also associated with elevated levels of seminal ROS [50].

\section{ROS and male reproductive hormones}

ROS generation, which can be elicited through various exogenous and endogenous pathways, may adversely affect the male reproductive potential by interfering with the endocrine axes both individually and via their cross-talks (Table 1).

\section{Exogenous factors \\ Psychological stress}

Psychological stress has been demonstrated as a cause of idiopathic male infertility and several studies have described a correlation between stress and impaired semen parameters [51-53]. It was reported that psychological stress can increase the circulating levels of cortisol and norepinephrine [54]. These hormones have a significant impact on increasing intracellular levels of ROS/reactive nitrogen species (RNS) to have damaging effects on cellular microstructures and activation of the immune and inflammatory systems [54, 55]. Psychological stress inhibits male reproductive functions by directly affecting the action of glucocorticoids on Leydig cells [11]. As a result, circulating testosterone levels decrease through suppression of androgen synthesis and induction of apoptosis of Leydig cells [56]. Psychological stress can also increase the serum levels of corticosterone (in animals) and cortisol (in humans), which then enhance the apoptotic frequency of Leydig cells

Table 1 Sources of reactive oxygen species (ROS), their mechanism of generation and effects on male reproductive hormones

\begin{tabular}{|c|c|c|}
\hline Sources of ROS & Mechanism of ROS generation & Effects on male reproductive hormones \\
\hline \multicolumn{3}{|l|}{ Exogenous sources } \\
\hline $\begin{array}{l}\text { Psychological } \\
\text { stress }\end{array}$ & $\begin{array}{l}\text { By increasing stress hormone (cortisol) levels and activating } \\
\text { the immune-inflammatory system }\end{array}$ & $\begin{array}{l}\text { Decreases serum testosterone and LH levels by suppressing } \\
\text { androgen synthesis and inducing Leydig cells apoptosis }\end{array}$ \\
\hline Heat stress & $\begin{array}{l}\text { By decreasing antioxidant enzyme activities, increasing NADPH } \\
\text { oxidase activity and disrupting mitochondrial homeostasis }\end{array}$ & $\begin{array}{l}\text { Disrupts Sertoli cell functions, decreases testosterone and LH } \\
\text { levels }\end{array}$ \\
\hline $\begin{array}{l}\text { Environmental } \\
\text { toxicants }\end{array}$ & By activating inflammatory mechanisms and cellular death & $\begin{array}{l}\text { Decreases Leydig and Sertoli cell functions, hormonal } \\
\text { biosynthesis }\end{array}$ \\
\hline $\begin{array}{l}\text { Electromagnetic } \\
\text { radiations }\end{array}$ & By decreasing total antioxidant capacity & Decreases serum testosterone and LH levels \\
\hline $\begin{array}{l}\text { Long-term } \\
\text { heavy exercise }\end{array}$ & By stimulating mitochondrial enzymes including NOX and XO & Decreases LH, FSH, and testosterone levels \\
\hline Obesity & $\begin{array}{l}\text { By increasing leptin levels in human endothelial cells and } \\
\text { increasing mitochondrial fatty acid oxidation }\end{array}$ & $\begin{array}{l}\text { Activation of the HPG axis stimulates FSH and LH release. Leptin } \\
\text { can directly affect the gonads due to its receptor isoforms in } \\
\text { gonadal tissue and stimulate steroid secretion, through } \\
\text { increasing the GnRH }\end{array}$ \\
\hline $\begin{array}{l}\text { High-fat and } \\
\text { high-protein } \\
\text { food }\end{array}$ & $\begin{array}{l}\text { By decreasing natural food antioxidants and free radical } \\
\text { scavengers }\end{array}$ & $\begin{array}{l}\text { Decreases testosterone biosynthesis, LH secretion and androger } \\
\text { profile }\end{array}$ \\
\hline Alcohol & $\begin{array}{l}\text { By stimulating cytochrome P450s enzyme activities in the liver, } \\
\text { altering levels of necessary metals in the body, and reducing } \\
\text { antioxidant levels }\end{array}$ & $\begin{array}{l}\text { Increases Sertoli cells and Leydig cells apoptosis, reduces serum } \\
\text { testosterone, LH and FSH levels }\end{array}$ \\
\hline $\begin{array}{l}\text { Marijuana and } \\
\text { narcotic drugs }\end{array}$ & $\begin{array}{l}\text { By increasing inflammation and cytochrome p53-induced } \\
\text { apoptotic cell death }\end{array}$ & $\begin{array}{l}\text { Inhibits GnRH release and LH production, inhibits HPG axis, } \\
\text { reduces testosterone level, and increases SHBG level }\end{array}$ \\
\hline Smoking & $\begin{array}{l}\text { By decreasing oxygen delivery to the testis and the high } \\
\text { metabolic requirements of spermatogenesis, releasing a large } \\
\text { number of mutagens and metabolites, weakening of the } \\
\text { antioxidant defense systems. Stimulation of NOX enzymes }\end{array}$ & $\begin{array}{l}\text { Alters plasma levels of testosterone, prolactin, estradiol, FSH, LH } \\
\text { and SHBG by affecting the Leydig and Sertoli cells }\end{array}$ \\
\hline $\begin{array}{l}\text { Anabolic } \\
\text { steroids }\end{array}$ & $\begin{array}{l}\text { By stimulating mitochondrial respiratory chain complexes, } \\
\text { inflammatory cytokine release and cellular apoptosis }\end{array}$ & $\begin{array}{l}\text { Disrupts Leydig cell functions, suppresses HPG axis, reduces LH } \\
\text { release and thus testicular testosterone biosynthesis }\end{array}$ \\
\hline \multicolumn{3}{|l|}{ Endogenous sources } \\
\hline Aging & $\begin{array}{l}\text { By decreasing the activities of antioxidant enzymes, alteration } \\
\text { in the mitochondrial membrane potential }\end{array}$ & $\begin{array}{l}\text { Increases lipid peroxidation of Leydig cells, LH sensitivity by } \\
\text { diminishing LH receptors, reduces the rate of steroidogenesis, } \\
\text { testosterone biosynthesis and secretion }\end{array}$ \\
\hline $\begin{array}{l}\text { Infections of the } \\
\text { reproductive } \\
\text { tract }\end{array}$ & $\begin{array}{l}\text { Bacterial strains that colonize the male reproductive tract } \\
\text { causes inflammatory damage by inducing leukocyte migration, } \\
\text { release of cytokines and other inflammatory mediators, } \\
\text { activation of macrophages, lymphocytes and other } \\
\text { immunoreactive cells }\end{array}$ & $\begin{array}{l}\text { Reduces serum testosterone levels by disrupting the hormonal } \\
\text { axis, increase in LH and FSH levels }\end{array}$ \\
\hline
\end{tabular}


[57]. Furthermore, during glucocorticoid production by $11 \beta$-hydroxysteroid dehydrogenase-1 (11ßHSD-1), $\mathrm{NADPH}$ was produced as a cofactor that is used for the biosynthesis of steroidogenic enzymes and testosterone [58].

Stress adversely affects steroidogenesis, since changes in the autonomic catecholaminergic activities during stress may suppress Leydig cell functions, thus inhibiting steroidogenic enzyme activities and testosterone production [11]. Stress-induced elevations of glucocorticoid levels can directly decrease testosterone levels without altering LH levels [59-61]. Further, in case of chronic stress, a decrease in LH and GnRH levels becomes apparent $[62,63]$.

\section{Heat stress on gonads}

In males, testes are suspended in a scrotum outside the body in order to keep the temperature 2 to $4{ }^{\circ} \mathrm{C}$ lower than that of core body temperature. This is a requirement for normal spermatogenesis [64]. However, heat stress to the testes not only decreases semen quality but also indirectly lowers embryo quality after fertilization as the spermatozoa produced in overheated testis exhibits damage [65-67]. In this context, heat stress is responsible for enhancing ROS production as well as decreasing antioxidant enzyme activities, increasing NADPH oxidase activity and disrupting mitochondrial homeostasis $[68,69]$. Numerous reports have documented that factors such as fever, sauna or steam room use, sleeping posture, long time sitting or driving, polyester-lined athletic supports, using a laptop on the lap and electric blankets impose negative effects on scrotal temperatures and subsequently spermatogenesis [70, 71]. Studies have also reported that clinical conditions such as cryptorchidism, varicocele, and acute febrile illness can increase testicular temperature and suppress spermatogenesis [70].

Activation of the hypothalamic-pituitary-adrenal (HPA) axis and the consequent increase in plasma glucocorticoid concentrations are two of the most important responses to heat stress. Heat stress imparts detrimental effects on male reproduction partly by disrupting the normal release of GnRH from the hypothalamus as well as LH and FSH from the anterior pituitary gland [72]. Several studies have indicated that testicular heat stress leads to a decline in the circulating levels of testosterone and $\mathrm{LH}$ but increases serum cortisol levels [73, 74]. Testicular heat stress also leads to Leydig cell apoptosis and a reduction in testosterone biosynthesis in adult rat testes [75]. Moreover, increased testicular temperature adversely affects Sertoli cell function, production of testicular androgen-binding protein, spermatogenesis and semen parameters [76]. Thus, increased heat stress elevates the generation of ROS in the male reproductive tract by directly affecting cellular metabolism [69] and by influencing stress hormone levels [77].
The resulting increase in ROS production, in turn, damages testicular germ cells and other endocrine cells to disrupt the hormonal balance, thereby curbing male fertility [34].

\section{Environmental toxicants}

Exposure to environmental contaminants adversely affects the male reproductive potential [78, 79]. Male infertility caused by exposure to environmental toxicants such as cadmium [80,81], mercury [82, 83], bisphenol A (BPA) $[84,85]$ and dioxin [86] is a worldwide problem. Even chemical components of air pollution can induce OS by triggering redox-sensitive pathways subsequently leading to various malaise, such as inflammation and cell death [87].

These contaminations deteriorate semen parameters, DNA integrity via disrupting Leydig and Sertoli cell function, hormone biosynthesis, gene expression and epigenetic modifications [12, 88, 89]. These toxicants commonly act as 'endocrine disrupting chemicals' (EDCs) that interfere with normal hormonal functions [90], enhance the level of circulating cortisol owing to OS induction [91] and reduces circulating testosterone levels [92, 93]. Increased cortisol decreases LH secretion through crosstalk between the HPG-HPA axes. Decreased LH concentration fails to stimulate the Leydig cells resulting in decreased testosterone production, whereas decreased FSH affects normal Sertoli cell functions [94]. These toxicants also interfere with the cellular communications and adhesions between Sertoli-Sertoli cells and Sertoli-germ cells via the phosphatidylinositol 3-kinase (PI3K)/c-Src/focal adhesion kinase (FAK) signalling pathway which leads to reproductive dysfunction [95] and disrupted hormonal secretion. Thus, these toxicants disrupt normal male reproductive hormonal balance by their disruptive influence upon the endocrine and reproductive organs as well as by interfering in the cross-talk among different endocrine axes [96].

\section{Electromagnetic radiations}

Since the last few decades, it has been widely reported that long-term exposure to electromagnetic radiations can generate ROS in reproductive organs, which not only declines motility, viability, and normal morphology of functional spermatozoa [97, 98], but also disorients reproductive hormonal profiles. The use of cell phones [99], wireless internet [100] and other occupational or environmental radiations [101] are found to be major causative factors directly augmenting ROS generation in male reproductive organs [102, 103]. Electromagnetic radiation affects the HPA axis and increases adrenocorticotropic hormone $(\mathrm{ACTH})$ secretion from the anterior pituitary thereby increasing the production of cortisol from adrenal cortex [104]. These radiations can also decrease testosterone secretion from Leydig cells by 
disrupting the male reproductive hormonal axis [105]. Electromagnetic radiation significantly affect LH levels but not FSH and PRL levels [106]. It has also been reported that exposure to electromagnetic waves directly affects the pineal gland, thereby deteriorating the biological effect of melatonin on GnRH pulse in the hypothalamus [107]. Thus, altered GnRH levels influence FSH and LH secretion and negatively affects testosterone synthesis in the testis [108].

\section{Exercise}

Contrary to regular exercise that enhances antioxidant defences in the body, unaccustomed and/or exhaustive exercise can lead to the undesirable generation of excessive ROS [109]. Although the exact redox mechanisms remain elusive, it seems that mitochondria, NADPH oxidase (NOX), and xanthine oxidase (XO) are the major endogenous sources of ROS in skeletal muscle [109]. Some studies showed that moderate physical activity can increase FSH, LH, and testosterone levels [110], which is widely associated with increased energy and muscle strength [111, 112]. Despite the impact of moderate exercise, data suggest that vigorous exercise may decrease LH, FSH, and testosterone levels as well as semen parameters $[113,114]$. However, other investigators have reported that testosterone levels remain unaltered following heavy exercise $[115,116]$.

\section{Obesity}

Obesity is a complex health disorder that severely affects hormonal balance [117]. Obesity disrupts serum levels of leptin [118], ghrelin [119], adiponectin [120], orexin [121], obestatin [122] and other metabolic hormone profiles [117]. Reportedly, leptin correlates positively with body fat mass $[123,124]$ and a leptin-induced generation of ROS in human endothelial cells result from increased mitochondrial fatty acid oxidation [123, 124]. The activation of the HPG axis could be enhanced by leptin and thus stimulate the release of GnRH, FSH and LH [125]. Moreover, leptin can directly affect the gonads due to its receptor isoforms in gonadal tissue [125].

Though the impact of ghrelin on serum testosterone level is contentious [126-128], it is reported that ghrelin receptors are present in the testis and that ghrelin plays a key role in testosterone production, but not directly in spermatogenesis [126]. Increased ROS levels appear to cause increased levels of ghrelin [129] which may, in turn, result in obesity and further ROS production.

Serum adiponectin level is negatively correlated with both testosterone [130] and ROS production [131]. Orexin (hypocretin) is known to stimulate testosterone production by enhancing the activities of steroidogenic enzymes in Leydig cells [132]. It is also reported to attenuate ROS-induced cell damage [133]. All these metabolic hormones either directly or indirectly reduce the androgen profile in men.

The complex cross-talk among these hormones is interrupted in obesity, thus causing a massive annihilation of the hormonal milieu, which in turn affects male reproductive functions. Although there is a body of evidence highlighting the complexity and the multifactorial effects that obesity has on certain male reproductive functions, the correlation between obesity and semen parameters is still debated $[134,135]$.

\section{Food intake}

There is an inverse relationship between the dietary intake of antioxidant-rich food and incidence of human diseases [136]. Many naturally-occurring antioxidant compounds from plant sources have been identified as free radicals or active oxygen scavengers [136]. Studies show that men who consume high dietary fish, fruits, vegetables, legumes, whole grains and omega-3- and omega-6-fatty acids have better semen parameters compared with men consuming high fat, caffeine (>800 $\mathrm{mg} /$ day), red meat, processed meat, pizza, sugary drinks, and sweets in their diet $[137,138]$. Therefore, in order to compensate for poor nutritional vitamin intake, food and medicine are routinely supplemented with synthetic and natural food antioxidants.

It is well-known that chronic high-fat and high-protein diets lead to an increase in ROS generation and subsequently OS $[139,140]$ by disrupting the antioxidant defence [140] and mitochondrial metabolism $[139,141]$. This in turn negatively impacts semen quality through alteration of hormone levels [142, 143]. Antioxidant therapies may possibly have a beneficial impact on semen parameters, probably by protecting semen from ROS, reducing OS and improving basic sperm parameters. This improvement can be established by stimulation of testosterone biosynthesis, FSH and $\mathrm{LH}$ secretion, inhibin B and enhancement of androgen profile [144]. Investigators have showed that mainly selenium, coenzyme Q10 (CoQ10), and N-acetyl-cysteine can affect semen parameters by increasing testosterone and inhibin B [145]. However, further research is warranted to determine if there are any appropriate antioxidant compounds as well as suitable doses that could potentially be used in clinical practice.

\section{Alcohol}

Alcohol consumption promotes the generation of ROS through its metabolism pathway in the liver by stimulating the activity of cytochrome P450 enzymes, alteration of certain levels of metals (particularly free iron or copper ions) in the body, and finally, reduction in the antioxidant levels [146]. Due to the critical contribution of certain metals (particularly iron and copper) to the 
production of hydroxyl radical, anything that increases the levels of these metals can also promote ROS generation and OS [147]. It has been reported that alcohol increases iron levels in the body not only by iron-rich alcoholic beverages, such as red wine, but also by enhancing the absorption of iron from food [148].

Evidences in both animals and humans show that alcohol is also associated with high levels of estradiol and this finds relevance in the fact that estradiol enhances beta-endorphin release that is conventionally linked with the effects of alcohol consumption [149]. Chronic alcohol consumption can reduce serum testosterone, LH, and FSH levels by affecting the interactions between the neural and endocrine systems [149, 150]. Alcohol disrupts the cleavage of $\mathrm{GnRH}$ molecule from its precursor pre-pro $\mathrm{GnRH}$ and prevents the movement of protein kinase $\mathrm{C} 15$ which is necessary for the $\mathrm{GnRH}$-stimulation of LH and FSH [151, 152]. Eventually, this disrupts the endocrine balance and subsequently affects semen parameters [153].

Among testicular cells, Sertoli cells are those that are most affected by chronic alcohol consumption [154]. Since Sertoli cells contribute the most to testicular size, chronic alcohol abuse eventually causes testicular atrophy, degeneration of germ cells, decreased size of lumen of seminiferous tubules, an abundance of lipid droplets, vacuoles, dilatation of the blood vessels, variation in seminal vesicle diameter as well as apoptosis of Sertoli cells. Due to the intratesticular cross-talk between Sertoli and Leydig cells, Leydig cells are eventually also affected by these changes $[154,155]$. Though the correlation between alcohol consumption and infertility seems to be dose-dependent, the threshold of alcohol consumption beyond which would affect male fertility remains ambiguous [156].

\section{Opioids, narcotics and recreational drugs}

Opioids administration is associated with disrupted spermatogenesis and reduced sexual performance [157]. Both endogenous and exogenous opioids inhibit $\mathrm{GnRH}$ secretion, by disrupting the functions of HPG axis [158]. They reportedly generate ROS [159], induce inflammation as well as aid DNA/chromosomal damages and apoptosis in cells by p53 [160, 161]. Opioid consumption leads to increase in serum concentrations of sex hormone binding globulin (SHBG), a protein which tightly binds testosterone and E2 thus restricting the levels of unbound testosterone $[162,163]$. Therefore, for opioid users, the level of total testosterone and E2 remain subnormal [162, 163]. Consequently, decreased testosterone levels also result in the decrease of LH levels. The loss of integrity of the HPG axis via opioid actions on sex hormones and LH levels, lead to clinical hypogonadism $[162,164]$. The opioid methadone is also reported to significantly reduce testosterone levels by directly affecting steroidogenesis [158].

Marijuana contains the cannabinoid, delta-9-tetrahydrocannabinol (THC), which inhibits $\mathrm{GnRH}$ release and LH production [164]. Thus, THC, by imposing adversities upon the HPG axis and causing dose-dependent reduction in testosterone production, impairs spermatogenesis $[164,165]$ at different mitotic and meiotic stages, resulting in several morphogenetic sperm defects as well as gynecomastia, impaired libido, erectile and ejaculatory dysfunction [166].

Studies showed that heroin can decrease gonadotropin and testosterone levels by affecting the HPG axis [158]. Similarly, cocaine exposure can also disrupt normal gonadal functions and are associated with decreased testosterone production and HPG axis dysregulation [167].

Non-medical use of drug narcotics, such as hydrocodone and oxycodone can interfere with spermatogenesis through their effects on the hypothalamus, and suppress LH release [164].

\section{Smoking}

Smoking is a well-known cause of male subfertility/infertility [168]. A major mechanism for this effect appears to be ROS production by the interference of oxygen delivery to the testis which compromises the high metabolic requirements of spermatogenesis [168-170]. Smoking also releases a large number of mutagens and metabolites (including radioactive polonium, cadmium, benzopyrene, carbon monoxide, tar, naphthalene, and aromatic hydrocarbons) which disrupt the normal structure and function of the male reproductive organs [168, 169]. It may enhance OS not only directly through the production of reactive oxygen radicals in cigarette smoke, but also indirectly through the weakening of the antioxidant defence systems [171-173]. Studies have indicated that exposure to smoke can change plasma levels of testosterone, PRL, E2, FSH, LH and SHBG by effects on Leydig and Sertoli cells [171-173]. Studies have also shown that smoking is associated with alterations in semen quality of both fertile and infertile men by affecting pituitary, thyroid, adrenal and testicular functions [174].

\section{Anabolic steroids}

Regular consumption of exogenous steroids can produce ROS by disrupting mitochondrial respiratory chain complexes and lead to the release of inflammatory cytokines and apoptosis [175]. Exogenous steroid hormones inhibit spermatogenesis by suppressing the HPG axis, thus limiting the release of FSH and $\mathrm{LH}$ and in turn decreasing testosterone biosynthesis in the testis [176, 177]. Hypogonadism associated with anabolic androgenic steroid (AAS) abuse is usually reversible within 3-6 months after discontinuation. However, complete recovery takes 
more than 3 years or may even be impossible to achieve [164]. AAS abuse primarily produces Leydig cell alterations which lead to a decrease in testosterone synthesis [177]. However, disruption in the end stage of spermatogenesis with a lack of mature spermatozoa (oligozoospermia/ azoospermia), testicular atrophy, and morphologically-abnormal sperm have been reported in AAS consumers [178]. Following AAS discontinuation, Leydig cells start further proliferation but cellular counts generally remain less than normal, accounting for delayed recovery of testosterone levels and the occasional irreversible effects of AAS [179].

\section{Endogenous factors}

Though endogenous ROS is necessary for normal male reproductive functions, its excessive production may interfere with the endocrine axes and their cross-talk.

\section{Aging}

In the aged male, Leydig cells are oxidatively damaged due to excessive generation of endogenous ROS and decreased concentration and activity of antioxidant enzymes [180]. As a result of excessive ROS generation, oxidative modifications of DNA and alterations in the mitochondrial membrane potential required for testosterone synthesis take place [181, 182]. Alongside these changes, an increase in LH sensitivity due to diminishing LH receptors per cell and a reduced ability of LH to activate steroidogenic acute regulatory (StAR) protein, which transport cholesterol from the outer mitochondrial membrane to the inner, occurs $[183,184]$. Thus, overproduction of ROS may play a role in age-related testicular degeneration associated with male infertility [185].

The steroidogenic steps regulated by the P450 enzymes are the most likely sites of ROS action [186, 187]. FSH and human chorionic gonadotropin (hCG) together have been reported to stimulate ROS-producing cellular metabolisms affecting differentiation processes in germ cells $[185,188,189]$. Furthermore, following ROS production, the activities of several enzymes of the testosterone biosynthetic pathway are reduced, resulting in further decrease in testosterone synthesis and secretion $[190,191]$.

\section{Reproductive tract infections}

Reproductive tract infections is an important cause of disrupted male reproductive function and infertility [47]. Many immunoregulatory and pro-inflammatory cytokines are produced by testicular spermatogenic and somatic cells, both under normal conditions as well as during an inflammatory scenario [192]. Cytokines (such as IL-1, IL6 or TNF- $\alpha$ ) are even produced by non-immune cells like Leydig cells and Sertoli cells, that appear as typical components of seminal plasma to maintain normal spermatogenesis [192, 193]. Reproductive tract infections can be caused by ejaculatory duct inflammation, epididymitis, sexually transmitted infections (e.g. gonorrhoea, Chlamydia trachomatis, Escherichia coli, mycobacteria and Ureaplasma urealyticum), urethritis, testicular torsion, varicocele and several other causes like chronic prostatitis, inflammation of one or both testes (orchitis), and even by some drug therapy (escitalopram, tramadol, levonorgestrel etc.) $[47,194]$. With the progression of inflammatory damage and weakening of antioxidant defence, as a mitigation strategy against the colonised bacterial strains, there can be increased ROS levels in the male genital tract, affecting the prostate gland, seminal vesicles or the epididymis $[47,195]$.

Reproductive tract infections indirectly cause germ cell degeneration and disruption of spermatogenesis through either of the following occurrences [196]: (i) changes in testicular temperature following high fever; (ii) congestion of seminiferous tubule following interstitial oedema; or (iii) modification of testosterone production. Though studies on male sex hormones and reproductive tract infections are scanty, some investigators observed the reduction of testosterone together with an increase in $\mathrm{LH}$ and FSH levels in patients with reproductive tract infections [196-198]. It has been reported that in patients with chronic prostatitis, corticosterone level decreases, while testosterone level increases compared to normal controls [199]. Whereas in mumps orchitis, increased corticosterone level decreases both LH and FSH levels which results in reduced production of testosterone from Leydig cells [200].

\section{Hormonal influence on the oxidative status of male reproduction}

OS that occurs due to either the enhanced production of ROS or reduced availability of antioxidants may cause lipid peroxidation in Leydig cells and germ cells, damage to lipoproteins, protein aggregation and fragmentation, and steroidogenic enzyme inhibition [10]. Testicular OS causes a reduction in testosterone production, either as a result of the injury to the Leydig cells or to other endocrine structures like the anterior pituitary [201, 202]. Reportedly, normal steroidogenesis also generates ROS, which are largely produced by mitochondrial respiration and the catalytic reactions of the steroidogenic cytochrome P450 enzymes [186]. ROS generated in this way, in turn, have been identified to inhibit subsequent steroid productions, and to damage mitochondrial membranes of spermatozoa [203]. OS is associated with increased numbers of immature spermatozoa via an indirect effect on the male hormone production that is correlated with spermatogenesis [204, 205].

It has been reported that systemic hormones (FSH, $\mathrm{LH}$, testosterone, E2, PRL) may regulate seminal total 
antioxidant capacity (TAC) [206, 207]. A positive relationship between PRL or free T4 (fT4) and a negative correlation between gonadotropins or gonadal steroids with TAC have also been shown [22]. It is evident that some hormones like testosterone and MLT may act as antioxidants to protect sperm and other testicular cells from damage induced by ROS [208, 209]. Other metabolites of the steroidogenic pathway like DHEA are reported to enhance the level of cellular antioxidants, but the proper mechanism is still unclear [210]. Direct and indirect relationships between testosterone and antioxidant levels like selenium and/or CoQ10 and between testosterone and zinc in infertile men, respectively, have been observed [207, 211]. CoQ10 can decrease FSH and LH levels [212]. A negative relationship has been found between serum level of testosterone, E2, fT4 and sperm DNA damage [213, 214]. Also, the antioxidant inhibition could affect triiodothyronine (T3), thyroxine (T4), neurotransmitter noradrenaline and increase sperm DNA damage [215]. Intramuscular or subcutaneous injection of highly purified FSH to idiopathic infertile men reduces ROS production [216] and the subsequent sperm DNA damage [217]. Although it has been reported that testosterone could produce DNA fragmentation in Sertoli and germ cells by stimulating caspase activities in Sertoli cells [218], long-term effects of antioxidants can alter FSH, testosterone, and inhibin B levels [219].

\section{Mechanism of action}

Innumerable exogenous and endogenous factors, as discussed above, can produce ROS in the male reproductive system by disrupting the balance of oxidants and antioxidants. Following the generation of ROS, the HPA axis becomes activated and releases corticosterone (in animals) and cortisol (in humans) in response to stress. These stress hormones, through the cross-talk between the HPG and HPA axes, negatively affect LH secretion from the anterior pituitary. Decreased LH fails to stimulate Leydig cells to produce enough testosterone. Decreased FSH diminishes the release of androgen-binding protein (ABP) from the Sertoli cells, and thus, an overall decline in circulating testosterone occurs during severe OS.

ROS also affect HPT axis to reduce T3 and T4 secretion. Decreased T3 reduces the levels of the StAR mRNA and protein in Leydig cells, as well as testosterone production [220]. Increased OS also decreases the secretion of insulin from the pancreas which further negatively affects T3 release from the thyroid gland and thereby testosterone biosynthesis.

Conditions such as obesity not only involve the HPA and HPT axes, it also includes several metabolic hormones that manifest ROS-induced alterations in male reproductive functions. Obesity-induced ROS can affect adipocytes to secrete more leptin, which together with insulin, negatively regulate T3-release and thereby inhibit testicular functions. Leptin, secreted by adipocytes also inhibit $\mathrm{GnRH}$ release from the hypothalamus.

Testicular E2 and inhibin are produced intensely during OS, which then inhibit testosterone release. Following ROS exposure, aromatase activity increases which result in more E2 production. ROS exposure is also reported to increase PRL secretion from anterior pituitary which causes decreased GnRH release. Infections in the reproductive tract can lead to the production of pro-inflammatory cytokines (TNF- $\alpha$, IL-1b, and IL-6) which again inhibit both GnRH release and testosterone secretion.

Thus, through its actions on an individual hormonal axis and/or by disrupting the cross-talk among different endocrine systems, ROS can lead to decreased testosterone production as the outcome of endocrine disruption. Decreased testosterone fails to regulate spermatogenesis properly to produce enough mature spermatozoa. It also fails to maintain the normal growth of accessory reproductive organs which play crucial roles in sperm maturation. As a prime regulator of male reproductive behaviour, testosterone deficiency may lead to suppressed sexual behaviour among men. Thus, by disrupting the endocrine reproductive functions, ROS may result in male infertility (Fig. 1).

\section{Conclusion}

This review summarizes the alterations of the reproductive endocrinological status by numerous endogenous and exogenous sources of ROS. Pivotal hormonal regulators of male reproductive functions can be affected by the disruption of the balance between ROS production and the antioxidant defence mechanism in the male reproductive system. Uncontrolled generation of ROS may directly damage reproductive tissues or can interfere with the normal regulatory mechanisms of the HPG axis and its crosstalk with other endocrine axes, to adversely affect male reproductive functioning, thereby inducing male infertility.

\section{Abbreviations \\ 11ß-HSD: 11ß-hydroxysteroid dehydrogenase; AAS: Anabolic androgenic steroid; AMH: Anti-Mullerian hormone; CORT: Corticosterone; delta-9-THC: Delta-9- tetrahydrocannabinol; DHEA: Dehydroepiandrosterone; E2: Estradiol; FSH: Follicle- stimulating hormone; fT4: Free T4; GC: Glucocorticoid; GnRH: Gonadotropin releasing hormone; HPG: Hypothalamic-pituitary-gonadal; LH: Luteinizing hormone; MLT: Melatonin; NOX: NADPH oxidase; OS: Oxidative stress; PRL: Prolactin; ROS: Reactive oxygen species; SHBG: Sex hormone binding globulin; TAC: Total antioxidant capacity; XO: Xanthine oxidase}

\section{Acknowledgements}

Authors acknowledge the support by the American Center for Reproductive Medicine, Cleveland Clinic, USA. 


\section{Authors' contributions}

$M D$ and SD drafted this article and contributed equally in the writing of the manuscript. AA conceived the original design for this study and supervised the project. PS, DD and RH revised the article critically for its scientific content and edited the manuscript and MRS helped supervise the writing of the manuscript. All authors read and approved the final manuscript.

\section{Ethics approval and consent to participate}

Not applicable.

\section{Consent for publication}

Not applicable.

\section{Competing interests}

The authors declare that they have no competing interests.

\section{Publisher's Note}

Springer Nature remains neutral with regard to jurisdictional claims in published maps and institutional affiliations.

\begin{abstract}
Author details
${ }^{1}$ Reproductive Biotechnology Research Center, Avicenna Research Institute, Academic Center for Education, Culture and Research, Tehran, Iran. ${ }^{2}$ American Center for Reproductive Medicine, Cleveland Clinic, Cleveland, Ohio 44195, USA. ${ }^{3}$ Department of Physiology, Faculty of Medicine, MAHSA University, Jalan SP2, Bandar Saujana Putra, 42610 Jenjarom, Selangor, Malaysia. ${ }^{4}$ Department of Physiology, Faculty of Medicine, Universiti Teknologi MARA, Sungai Buloh Campus, Jalan Hospital, 47000 Sungai Buloh Selangor, Malaysia. ${ }^{5}$ Department of Medical Biosciences, University of the Western Cape, Bellville, Cape Town 7535, South Africa. ${ }^{6}$ Reproductive Immunology Research Center, Avicenna Research Institute, Academic Center for Education, Culture and Research, Tehran, Iran.
\end{abstract}

\section{Received: 14 June 2018 Accepted: 30 August 2018}

Published online: 11 September 2018

\section{References}

1. Carlsen E, Giwercman A, Keiding N, Skakkebaek NE. Evidence for decreasing quality of semen during past 50 years. Bmj. 1992;305(6854):609-13.

2. Swan SH, Elkin EP, Fenster L. The question of declining sperm density revisited: an analysis of 101 studies published 1934-1996. Environ Health Perspect. 2000;108(10):961.

3. Rolland M, Le Moal J, Wagner V, Royère $D$, De Mouzon J. Decline in semen concentration and morphology in a sample of 26609 men close to general population between 1989 and 2005 in France. Hum Reprod. 2012;28(2):462-70.

4. Sengupta P, Dutta S, Krajewska-Kulak E. The disappearing sperms: analysis of reports published between 1980 and 2015. Am J Mens Health. 2017;11(4): 1279-1304

5. Sikka SC. Relative impact of oxidative stress on male reproductive function Curr Med Chem. 2001;8(7):851-62.

6. Agarwal A, Prabakaran SA. Mechanism, measurement, and prevention of oxidative stress in male reproductive physiology. Indian J Exp Biol. 2005; 43(11):963-74.

7. Rakhit M, Gokul SR, Agarwal A, du Plessis SS. Antioxidant strategies to overcome OS in IVF-embryo transfer. In: Studies on Women's Health. Editors: Agarwal, A., Aziz, N. and Rizk, B. Humana Press, Springer Science +Business Media, New York; 2013. p. 237-262.

8. Barazani Y, Katz BF, Nagler HM, Stember DS. Lifestyle, environment, and male reproductive health. Urol Clin North Am. 2014;41(1):55-66.

9. Sullivan LB, Chandel NS. Mitochondrial reactive oxygen species and cancer. Cancer Metab. 2014;2:17

10. Darbandi S, Darbandi M. Lifestyle modifications on further reproductive problems. Cresco J Reprod Sci. 2016;1(1):1-2.

11. Hardy MP, Gao H-B, Dong Q, Ge R, Wang Q, Chai WR, et al. Stress hormone and male reproductive function. Cell Tissue Res. 2005;322(1):147-53.

12. Diamanti-Kandarakis E, Bourguignon J-P, Giudice LC, Hauser R, Prins GS, Soto AM, et al. Endocrine-disrupting chemicals: an Endocrine Society scientific statement. Endocr Rev. 2009;30(4):293-342.
13. Spiers JG, Chen HJ, Sernia C, Lavidis NA. Activation of the hypothalamicpituitary-adrenal stress axis induces cellular oxidative stress. Front Neurosci. 2014;8:456.

14. Appasamy M, Muttukrishna S, Pizzey A, Ozturk O, Groome N, Serhal P, et al. Relationship between male reproductive hormones, sperm DNA damage and markers of oxidative stress in infertility. Reprod BioMed Online. 2007; 14(2):159-65.

15. Baker $H$, Burger $H$, de Kretser D, Hudson B (1986) Relative incidence of etiologic disorders in male infertility. In: Santen RJ, Swerdloff RS (eds) Male reproductive dysfunction: diagnosis and management of hypogonadism, infertility and impotence. Marcel Dekker, New York, pp 341-372.

16. Santen R, Paulsen C. Hypogonadotropic eunuchoidism. I. Clinical study of the mode of inheritance. J Clin Endocrinol Metab. 1973;36(1):47-54.

17. Kavoussi P, Costabile RA, Salonia A. Clinical urologic endocrinology: principles for Men's health. London: Springer; 2012.

18. Jameson JL. Harrison's endocrinology, 4E. New York: McGraw-Hill Education; 2016

19. Patton PE, Battaglia DE. Office andrology. New York: Humana Press; 2007.

20. Byrd W, Bennett MJ, Carr BR, Dong Y, Wians F, Rainey W. Regulation of biologically active dimeric inhibin a and B from infancy to adulthood in the male. J Clin Endocrinol Metab. 1998;83(8):2849-54.

21. Raivio T, Perheentupa A, McNeilly AS, Groome NP, Anttila R, Siimes MA, et al. Biphasic increase in serum inhibin B during puberty: a longitudinal study of healthy Finnish boys. Pediatr Res. 1998;44(4):552-6.

22. Mancini A, Festa R, Silvestrini A, Nicolotti N, Di Donna V, La Torre G, et al. Hormonal regulation of total antioxidant capacity in seminal plasma. J Androl. 2009;30(5):534-40.

23. Parker CR. Dehydroepiandrosterone and dehydroepiandrosterone sulfate production in the human adrenal during development and aging. Steroids. 1999;64(9):640-7.

24. Jacob MH, DdR J, Belló-Klein A, Llesuy SF, Ribeiro MF. Dehydroepiandrosterone modulates antioxidant enzymes and Akt signaling in healthy Wistar erat hearts. J Steroid Biochem Mol Biol. 2008;112(1):138-44.

25. Lu C, Yang W, Chen M, Liu T, Yang J, Tan P, et al. Inhibin a inhibits folliclestimulating hormone (FSH) action by suppressing its receptor expression in cultured rat granulosa cells. Mol Cell Endocrinol. 2009;298(1-2):48-56.

26. Li C, Zhou X. Melatonin and male reproduction. Clin Chim Acta. 2015;446:175-80.

27. Awad H, Halawa F, Mostafa T, Atta H. Melatonin hormone profile in infertile males. Int J Androl. 2006;29(3):409-13.

28. La Marca A, Sighinolfi G, Radi D, Argento C, Baraldi E, Artenisio AC, et al. Anti-Müllerian hormone (AMH) as a predictive marker in assisted reproductive technology (ART). Hum Reprod Update. 2010;16(2):113-30.

29. Holdcraft RW, Braun RE. Hormonal regulation of spermatogenesis. Int J Androl. 2004;27(6):335-42.

30. Trigo RV, Bergadá I, Rey R, Ballerini MG, Bedecarrás P, Bergadá C, et al. Altered serum profile of inhibin B, pro-aC and anti-Müllerian hormone in prepubertal and pubertal boys with varicocele. Clin Endocrinol. 2004;60(6): 758-64.

31. Castañeda Cortés DC, Langlois VS, Fernandino Jl. Crossover of the hypothalamic pituitary-adrenal/Interrenal, -thyroid, and -gonadal axes in testicular development. Front Endocrinol. 2014;5:139.

32. Bisht $S$, Faiq M, Tolahunase M, Dada R. Oxidative stress and male infertility. Nat Rev Urol. 2017;14(8):470-85.

33. Gosalvez J, Trrda E, Agarwal A. Free radical and superoxide reactivity detection in semen quality assessment: past, present, and future. J Assist Reprod Genet. 2017;34:697-707.

34. Agarwal A, Virk G, Ong C, du Plessis SS. Effect of oxidative stress on male reproduction. World J Men's Health. 2014;32(1):1-17.

35. Ramalho-Santos J, Varum S, Amaral S, Mota PC, Sousa AP, Amaral A. Mitochondrial functionality in reproduction: from gonads and gametes to embryos and embryonic stem cells. Hum Reprod Update. 2009;15(5):553-72.

36. Kussmaul $L$, Hirst J. The mechanism of superoxide production by NADH: ubiquinone oxidoreductase (complex I) from bovine heart mitochondria. Proc Natl Acad Sci U S A. 2006;103(20):7607-12.

37. Vinogradov AD, Grivennikova VG. Generation of superoxide-radical by the NADH:ubiquinone oxidoreductase of heart mitochondria. Biochem Mosc. 2005;70(2):120-7.

38. Kehrer JP. The Haber-Weiss reaction and mechanisms of toxicity. Toxicology. 2000;149(1):43-50

39. Blaylock MG, Cuthbertson BH, Galley HF, Ferguson NR, Webster NR. The effect of nitric oxide and peroxynitrite on apoptosis in human polymorphonuclear leukocytes. Free Radic Biol Med. 1998;25(6):748-52. 
40. Sabeur K, Ball B. Characterization of NADPH oxidase 5 in equine testis and spermatozoa. Reprod. 2007;134(2):263-70.

41. Petrushanko IY, Lobachev VM, Kononikhin AS, Makarov AA, Devred F, Kovacic H, et al. Oxidation of capital ES, Cyrillicsmall a, Cyrillic2+-binding domain of NADPH oxidase 5 (NOX5): toward understanding the mechanism of inactivation of NOX5 by ROS. PLoS One. 2016;11(7):e0158726.

42. Rengan AK, Agarwal A, van der Linde M, du Plessis SS. An investigation of excess residual cytoplasm in human spermatozoa and its distinction from the cytoplasmic droplet. Reprod Biol Endocrinol. 2012;10(1):92.

43. Saleh RA, Agarwal A, Nada EA, El-Tonsy MH, Sharma RK, Meyer A, et al. Negative effects of increased sperm DNA damage in relation to seminal oxidative stress in men with idiopathic and male factor infertility. Fertil Steril. 2003:79:1597-605.

44. Gharagozloo P, Aitken RJ. The role of sperm oxidative stress in male infertility and the significance of oral antioxidant therapy. Hum Reprod. 2011;26(7):1628-40.

45. Lavranos G, Balla M, Tzortzopoulou A, Syriou V, Angelopoulou R. Investigating ROS sources in male infertility: a common end for numerous pathways. Reprod Toxicol. 2012;34(3):298-307.

46. Agarwal A, Saleh RA, Bedaiwy MA. Role of reactive oxygen species in the pathophysiology of human reproduction. Fertil Steril. 2003:79(4):829-43.

47. Azenabor A, Ekun AO, Akinloye O. Impact of inflammation on male reproductive tract. J Reprod Infertil. 2015;16(3):123.

48. World Health Organization. WHO laboratory manual for the examination and processing of human semen. Fifth Edition. WHO: Geneva, 2010.

49. Agarwal A, Prabakaran S, Allamaneni SS. Relationship between oxidative stress, varicocele and infertility: a meta-analysis. Reprod BioMed Online. 2006;12(5):630-3.

50. Shiraishi K, Matsuyama H, Takihara H. Pathophysiology of varicocele in male infertility in the era of assisted reproductive technology. Int J Urol. 2012; 19(6):538-50.

51. Clarke RN, Klock SC, Geoghegan A, Travassos DE. Relationship between psychological stress and semen quality among in-vitro fertilization patients. Hum Reprod. 1999;14(3):753-8.

52. Lampiao F. Variation of semen parameters in healthy medical students due to exam stress. Malawi Med J. 2009;21(4):166-7.

53. Gollenberg AL, Liu F, Brazil C, Drobnis EZ, Guzick D, Overstreet JW, et al. Semen quality in fertile men in relation to psychosocial stress. Fertil Steril. 2010;93(4):1104-11.

54. Flaherty RL, Owen M, Fagan-Murphy A, Intabli H, Healy D, Patel A, et al. Glucocorticoids induce production of reactive oxygen species/reactive nitrogen species and DNA damage through an iNOS mediated pathway in breast cancer. Breast Cancer Res. 2017;19(1):35.

55. Bakunina N, Pariante CM, Zunszain PA. Immune mechanisms linked to depression via oxidative stress and neuroprogression. Immunol. 2015;144(3): 365-73.

56. O'Hara L, McInnes K, Simitsidellis I, Morgan S, Atanassova N, SlowikowskaHilczer $J$, et al. Autocrine androgen action is essential for Leydig cell maturation and function, and protects against late-onset Leydig cell apoptosis in both mice and men. FASEB J. 2015;29(3):894-910.

57. Gao HB, Tong MH, Hu YQ, Guo QS, Ge R, Hardy MP. Glucocorticoid induces apoptosis in rat leydig cells. Endocrinol. 2002;143(1):130-8.

58. MacAdams MR, White RH, Chipps BE. Reduction of serum testosterone levels during chronic glucocorticoid therapy. Ann Intern Med. 1986;104(5):648-51.

59. Norman R. Effects of corticotropin-releasing hormone on luteinizing hormone, testosterone, and cortisol secretion in intact male rhesus macaques. Biol Reprod. 1993;49(1):148-53.

60. Orr T, Taylor M, Bhattacharyya A, Collins D, Mann D. Acute immobilization stress disrupts testicular steroidogenesis in adult male rats by inhibiting the activities of 17a-hydroxylase and 17, 20-Lyase without affecting the binding of LH/hCG receptors. J Androl. 1994;15(4):302-8.

61. Gao H-B, Tong M-H, Hu Y-Q, You H-Y, Guo Q-S, Ge R-S, et al. Mechanisms of glucocorticoid-induced Leydig cell apoptosis. Mol Cell Endocrinol. 2003; 199(1):153-63.

62. Almeida S, Anselmo-Franci J, Silva AR e, Carvalho TL. Chronic intermittent immobilization of male rats throughout sexual development: a stress protocol. Exp Physiol. 1998;83(05):701-4.

63. Wagenmaker ER, Breen KM, Oakley AE, Tilbrook AJ, Karsch FJ. Psychosocial stress inhibits amplitude of gonadotropin-releasing hormone pulses independent of cortisol action on the type II glucocorticoid receptor. Endocrinol. 2009;150(2):762-9.
64. Ivell R. Lifestyle impact and the biology of the human scrotum. Reprod Biol Endocrinol. 2007;5(1):15.

65. Paul C, Murray AA, Spears N, Saunders PT. A single, mild, transient scrotal heat stress causes DNA damage, subfertility and impairs formation of blastocysts in mice. Reprod. 2008;136(1):73-84.

66. Paul C, Teng S, Saunders PT. A single, mild, transient scrotal heat stress causes hypoxia and oxidative stress in mouse testes, which induces germ cell death. Biol Reprod. 2009;80(5):913-9.

67. Yaeram J, Setchell BP, Maddocks S. Effect of heat stress on the fertility of male mice in vivo and in vitro. Reprod Fertil Dev. 2006;18(6):647-53.

68. Moon EJ, Sonveaux P, Porporato PE, Danhier P, Gallez B, Batinic-Haberle I, et al. NADPH oxidase-mediated reactive oxygen species production activates hypoxia-inducible factor-1 (HIF-1) via the ERK pathway after hyperthermia treatment. Proc Natl Acad Sci. 2010;107(47):20477-82.

69. Belhadj Slimen I, Najar T, Ghram A, Dabbebi H, Ben Mrad M, Abdrabbah M. Reactive oxygen species, heat stress and oxidative-induced mitochondrial damage. Rev Int J Hyperthermia. 2014;30(7):513-23.

70. Jung A, Schuppe HC. Influence of genital heat stress on semen quality in humans. Andrologia. 2007;39(6):203-15.

71. Garolla A, Torino M, Sartini B, Cosci I, Patassini C, Carraro U, et al. Seminal and molecular evidence that sauna exposure affects human spermatogenesis. Hum Reprod. 2013;28(4):877-85.

72. Aggarwal A, Upadhyay R. Heat stress and hormones, in heat stress and animal productivity. India: Springer; 2013. p. 27-51.

73. Rhynes W, Ewing L. Testicular endocrine function in Hereford bulls exposed to high ambient temperature 1. Endocrinology. 1973;92(2):509-15.

74. Hansen PJ. Effects of heat stress on mammalian reproduction. Philosophical transactions of the Royal Society of London B. Biol Sci. 2009;364(1534):3341-50.

75. Li Z, Tian J, Cui G, Wang M, Yu D. Effects of local testicular heat treatment on Leydig cell hyperplasia and testosterone biosynthesis in rat testes. Reproduction, fertility. Development. 2016;28(9):1424-32.

76. Hagenas L, Ritzen EM, Svensson J, Hansson V, Purvis K. Temperature dependence of Sertoli cell function. Int J Androl. 1978;1(Supplement 2): $449-58$.

77. Megahed G, Anwar M, Wasfy S, Hammadeh M. Influence of heat stress on the cortisol and oxidant-antioxidants balance during Oestrous phase in buffalo-cows (Bubalus bubalis): Thermo-protective role of antioxidant treatment. Reprod Domest Anim. 2008;43(6):672-7.

78. Coutts SM, Fulton N, Anderson RA. Environmental toxicant-induced germ cell apoptosis in the human fetal testis. Hum Reprod. 2007;22(11):2912-8.

79. Wong W, Yan H, Li W, Lie P, Mruk D, Cheng C. Cell junctions in the testis as targets for toxicants. In: Richburg J, Hoyer P, editors. Comprehensive toxicology. Oxford: Elsevier; 2010. p. 167-88.

80. Benoff S, Hauser R, Marmar JL, Hurley IR, Napolitano B, Centola GM. Cadmium concentrations in blood and seminal plasma: correlations with sperm number and motility in three male populations (infertility patients, artificial insemination donors, and unselected volunteers). Mol Med. 2009; 15(7-8):248-62.

81. Luparello C, Sirchia R, Longo A. Cadmium as a transcriptional modulator in human cells. Crit Rev Toxicol. 2011;41(1):75-82.

82. Choy CM, Yeung QS, Briton-Jones CM, Cheung CK, Lam CW, Haines CJ. Relationship between semen parameters and mercury concentrations in blood and in seminal fluid from subfertile males in Hong Kong. Fertil Steril. 2002;78(2):426-8.

83. Mocevic E, Specht IO, Marott JL, Giwercman A, Jonsson BA, Toft G, et al. Environmental mercury exposure, semen quality and reproductive hormones in Greenlandic Inuit and European men: a cross-sectional study. Asian J Androl. 2013:15(1):97-104.

84. Welshons WV, Nagel SC, Vom Saal FS. Large effects from small exposures. III. Endocrine mechanisms mediating effects of bisphenol a at levels of human exposure. Endocrinology. 2006;147(6 Suppl):S56-69.

85. Calafat AM, Ye X, Wong LY, Reidy JA, Needham LL. Exposure of the U.S. population to bisphenol a and 4-tertiary-octylphenol: 2003-2004. Environ Health Perspect. 2008;1 16(1):39-44.

86. Galimova EF, Amirova ZK, Galimov Sh N. Dioxins in the semen of men with infertility. Environ Sci Pollut Res Int. 2015;22(19):14566-9.

87. Lodovici M, Bigagli E. Oxidative stress and air pollution exposure. Journal of toxicology. 2011;2011:1-9.

88. Pacey A. Environmental and lifestyle factors associated with sperm DNA damage. Hum Fertil. 2010;13(4):189-93. 
89. Skinner MK, Manikkam M, Guerrero-Bosagna C. Epigenetic transgenerational actions of environmental factors in disease etiology. Trends Endocrinol Metab. 2010;21(4):214-22.

90. Sengupta P. Dutta S. Metals. In M. K. Skinner (Ed.), Encyclopedia of Reproduction. vol. 1, pp. 579-587. Academic Press: Elsevier, Cambridge, Massachusetts, United States.

91. Güven M, Bayram F, Ünlühizarci K, Kelestimur F. Endocrine changes in patients with acute organophosphate poisoning. Hum Exp Toxicol. 1999;18(10):598-601.

92. Herath CB, Jin W, Watanabe G, Arai K, Suzuki AK, Taya K. Adverse effects of environmental toxicants, octylphenol and bisphenol $\mathrm{a}$, on male reproductive functions in pubertal rats. Endocrine. 2004;25(2):163-72.

93. Meeker JD, Rossano MG, Protas B, Padmanahban V, Diamond MP, Puscheck $E$, et al. Environmental exposure to metals and male reproductive hormones: circulating testosterone is inversely associated with blood molybdenum. Fertil Steril. 2010;93(1):130-40.

94. Shimon I, Lubina A, Gorfine M, llany J. Feedback inhibition of gonadotropins by testosterone in men with hypogonadotropic hypogonadism: comparison to the intact pituitary-testicular axis in primary hypogonadism. J Androl. 2006;27(3):358-64.

95. Sharma RP, Schuhmacher M, Kumar V. Review on crosstalk and common mechanisms of endocrine disruptors: scaffolding to improve PBPK/PD model of EDC mixture. Environ Int. 2017;99:1-14.

96. Sengupta $\mathrm{P}$, Banerjee R. Environmental toxins: alarming impacts of pesticides on male fertility. Hum Exp Toxicol. 2014;33(10):1017-39.

97. Vignera S, Condorelli RA, Vicari E, D'Agata R, Calogero AE. Effects of the exposure to mobile phones on male reproduction: a review of the literature. J Androl. 2012;33(3):350-6.

98. Darbandi M, Darbandi S, Agarwal A, Henkle R, Sadeghi MR. The effects of exposure to low frequency electromagnetic fields on male fertility. Altern Ther Health Med. 2017;23

99. Agarwal A, Singh A, Hamada A, Kesari K. Cell phones and male infertility: a review of recent innovations in technology and consequences. Int Braz J Urol. 2011;37(4):432-54.

100. Yildirim ME, Kaynar M, Badem H, Cavis M, Karatas OF, Cimentepe E. What is harmful for male fertility: cell phone or the wireless internet? Kaohsiung J Med Sci. 2015;31(9):480-4.

101. Al-Quzwini OF, Al-Taee HA, Al-Shaikh SF. Male fertility and its association with occupational and mobile phone towers hazards: an analytic study. Middle East Fertil Soc J. 2016;21(4):236-40.

102. Agarwal A, Deepinder F, Sharma RK, Ranga G, Li J. Effect of cell phone usage on semen analysis in men attending infertility clinic: an observational study. Fertil Steril. 2008;89(1):124-8.

103. Agarwal A, Desai NR, Makker K, Varghese A, Mouradi R, Sabanegh E, et al. Effects of radiofrequency electromagnetic waves (RF-EMW) from cellular phones on human ejaculated semen: an in vitro pilot study. Fertil Steril. 2009;92(4):1318-25.

104. Mahdavi SM, Sahraei H, Yaghmaei P, Tavakoli H. Effects of electromagnetic radiation exposure on stress-related behaviors and stress hormones in male wistar rats. Biomolecules Ther. 2014;22(6):570.

105. Meo SA, Al-Drees AM, Husain S, Khan MM, Imran MB. Effects of mobile phone radiation on serum testosterone in Wistar albino rats. Saudi Med J. 2010;31(8):869-73.

106. Merhi ZO. Challenging cell phone impact on reproduction: a review. J Assist Reprod Genet. 2012;29(4):293-7.

107. Stevens RG, Davis S. The melatonin hypothesis: electric power and breast cancer. Environ Health Perspects. 1996;104(Suppl 1):135.

108. Malpaux B, Daveau A, Maurice F, Gayrard V, Thiery J-C. Short-day effects of melatonin on luteinizing hormone secretion in the ewe: evidence for central sites of action in the mediobasal hypothalamus. Biol Reprod. 1993;48(4):752-60.

109. Adefuye AO, Adeola HA, Sales KJ, Katz AA. Seminal fluid-mediated inflammation in physiology and pathology of the female reproductive tract. J Immunol Res. 2016;2016:1-13.

110. Vaamonde D, Da Silva-Grigoletto ME, García-Manso JM, Barrera N, VaamondeLemos R. Physically active men show better semen parameters and hormone values than sedentary men. Eur J Appl Physiol. 2012;112(9):3267-73.

111. Grandys M, Majerczak J, Duda K, Zapart-Bukowska J, Kulpa J, Zoladz J. Endurance training of moderate intensity increases testosterone concentration in young, healthy men. Int J Sports Med. 2009;30(07):489-95.

112. Fahrner C, Hackney AC. Effects of endurance exercise on free testosterone concentration and the binding affinity of sex hormone binding globulin (SHBG). Int J Sports Med. 1998;19(01):12-5.
113. Flynn M, Pizza F, Brolinson P. Hormonal responses to excessive training: influence of cross training. Int J Sports Med. 1997;18(03):191-6.

114. Safarinejad MR, Azma K, Kolahi AA. The effects of intensive, long-term treadmill running on reproductive hormones, hypothalamus-pituitary-testis axis, and semen quality: a randomized controlled study. J Endocrinol. 2009; 200(3):259-71.

115. Kindermann W, Schnabel A, Schmitt W, Biro G, Cassens J, Weber F. Catecholamines, growth hormone, cortisol, insulin, and sex hormones in anaerobic and aerobic exercise. Eur J Appl Physiol Occup Physiol. 1982; 49(3):389-99.

116. Jurimae J, Jurimae T. Responses of blood hormones to the maximal rowing ergometer test in college rowers. J Sports Med Phys Fitness. 2001;41(1):73.

117. Kopelman PG. Hormones and obesity. Baillieres Clin Endocrinol Metab. 1994 8(3):549-75.

118. Ahima RS. Revisiting leptin's role in obesity and weight loss. J Clin Invest. 2008;118(7):2380.

119. Álvarez-Castro P, Pena L, Cordido F. Ghrelin in obesity, physiological and pharmacological considerations. Mini Rev Med Chem. 2013;13(4):541-52.

120. Kawano J, Arora R. The role of adiponectin in obesity, diabetes, and cardiovascular disease. J Cardiometab Syndr. 2009;4(1):44-9.

121. Perez-Leighton C, Butterick-Peterson T, Billington C, Kotz C. Role of orexin receptors in obesity: from cellular to behavioral evidence. Int J Obes. 2013; 37(2):167-74.

122. Ren A-J, Guo Z-F, Wang Y-K, Lin L, Zheng X, Yuan W-J. Obestatin, obesity and diabetes. Peptides. 2009;30(2):439-44.

123. Bouloumie A, Marumo T, Lafontan M, Busse R. Leptin induces oxidative stress in human endothelial cells. FASEB J. 1999;13(10):1231-8.

124. Yamagishi SI, Edelstein D, Du XL, Kaneda Y, Guzman M, Brownlee M. Leptin induces mitochondrial superoxide production and monocyte chemoattractant protein-1 expression in aortic endothelial cells by increasing fatty acid oxidation via protein kinase a. J Biol Chem. 2001; 276(27):25096-100.

125. Wauters M, Considine RV, Van Gaal LF. Human leptin: from an adipocyte hormone to an endocrine mediator. Eur J Endocrinol. 2000;143(3):293-311.

126. Ishikawa T, Fujioka H, Ishimura T, Takenaka A, Fujisawa M. Ghrelin expression in human testis and serum testosterone level. J Androl. 2007;28(2):320-4.

127. Wang L, Fang F, Li Y, Zhang Y, Pu Y, Zhang X. Role of ghrelin on testosterone secretion and the mRNA expression of androgen receptors in adult rat testis. Systems Biol Reprod Med. 2011;57(3):119-23.

128. Greenman $Y$, Rouach V, Limor R, Gilad S, Stern N. Testosterone is a strong correlate of ghrelin levels in men and postmenopausal women. Neuroendocrinology. 2009;89(1):79-85.

129. Suzuki H, Matsuzaki J, Hibi T. Ghrelin and oxidative stress in gastrointestinal tract. J Clin Biochem Nutr. 2010;48(2):122-5.

130. Page ST, Herbst KL, Amory JK, Coviello AD, Anawalt BD, Matsumoto AM, et al. Testosterone administration suppresses adiponectin levels in men. J Androl. 2005:26(1):85-92.

131. Yuan F, Li Y-N, Liu Y-H, Yi B, Tian J-W, Liu F-Y. Adiponectin inhibits the generation of reactive oxygen species induced by high glucose and promotes endothelial NO synthase formation in human mesangial cells. Mo Med Rep. 2012;6(2):449-53.

132. Zheng D, Zhao Y, Shen Y, Chang X, Ju S, Guo L. Orexin A-mediated stimulation of $3 \beta-H S D$ expression and testosterone production through MAPK signaling pathways in primary rat Leydig cells. J Endocrinol Investig. 2014:37(3):285-92.

133. Duffy CM, Nixon JP, Butterick TA. Orexin a attenuates palmitic acid-induced hypothalamic cell death. Mol Cell Neurosci. 2016;75:93-100.

134. Aggerholm AS, Thulstrup AM, Toft G, Ramlau-Hansen CH, Bonde JP. Is overweight a risk factor for reduced semen quality and altered serum sex hormone profile? Fertil Steril. 2008;90(3):619-26.

135. Al-Ali B M, Gutschi T, Pummer K, Zigeuner R, Brookman-May S, Wieland W, et al. Body mass index has no impact on sperm quality but on reproductive hormones levels. Andrologia. 2014;46(2):106-11.

136. Lobo V, Patil A, Phatak A, Chandra N. Free radicals, antioxidants and functional foods: impact on human health. Pharmacognosy Rev. 2010;4(8):118.

137. Chavarro JE, Toth TL, Sadio SM, Hauser R. Soy food and isoflavone intake in relation to semen quality parameters among men from an infertility clinic. Hum Reprod. 2008;23(11):2584-90.

138. Mendiola J, Torres-Cantero AM, Moreno-Grau JM, Ten J, Roca M, MorenoGrau $S$, et al. Food intake and its relationship with semen quality: a casecontrol study. Fertil Steril. 2009;91(3):812-8. 
139. Ruggiero C, Ehrenshaft M, Cleland E, Stadler K. High-fat diet induces an initial adaptation of mitochondrial bioenergetics in the kidney despite evident oxidative stress and mitochondrial ROS production. Am J Physiol Endocrinol Metab. 2011;300(6):8.

140. Kolodziej U, Maciejczyk M, Niklinska W, Waszkiel D, ZendzianPiotrowska M, Zukowski $P$, et al. Chronic high-protein diet induces oxidative stress and alters the salivary gland function in rats. Arch Oral Biol. 2017;84:6-12.

141. Kahle M, Schafer A, Seelig A, Schultheiss J, Wu M, Aichler M, et al. High fat diet-induced modifications in membrane lipid and mitochondrialmembrane protein signatures precede the development of hepatic insulin resistance in mice. Mol Metab. 2014;4(1):39-50.

142. Chakraborty TR, Donthireddy L, Adhikary D, Chakraborty S. Long-term high fat diet has a profound effect on body weight, hormone levels, and estrous cycle in mice. Med Sci Monit. 2016;22:1601-8.

143. Attaman JA, Toth TL, Furtado J, Campos H, Hauser R, Chavarro JE. Dietary fat and semen quality among men attending a fertility clinic. Hum Reprod. 2012; 27(5):1466-74.

144. Agarwal A, Sekhon LH. The role of antioxidant therapy in the treatment of male infertility. Hum Fertil (Camb). 2010;13(4):217-25.

145. Ahmadi S, Bashiri R, Ghadiri-Anari A, Nadjarzadeh A. Antioxidant supplements and semen parameters: an evidence based review. Int J Reprod Biomed. 2016; 14(12):729-36.

146. Wu D, Cederbaum Al. Alcohol, oxidative stress, and free radical damage. Alcohol Res Health. 2003;27:277-84

147. Qureshi GA, Memon SA, Memon AB, Ghouri RA, Memon JM, Parvez SH. The emerging role of iron, zinc, copper, magnesium and selenium and oxidative stress in health and diseases. Brill Online. 2005;19(2):147-69.

148. Whitfield JB, Zhu G, Heath AC, Powell LW, Martin NG. Effects of alcohol consumption on indices of iron stores and of iron stores on alcohol intake markers. Alcohol Clin Exp Res. 2001;25(7):1037-45.

149. Emanuele MA, Emanuele N. Alcohol and the male reproductive system. Alcohol Res Health. 2001;25(4):282-7.

150. Maneesh M, Dutta S, Chakrabarti A, Vasudevan D. Alcohol abuse-duration dependent decrease in plasma testosterone and antioxidants in males. Indian J Physiol Pharmacol. 2006;50(3):291.

151. Uddin S, Wilson T, Emanuele M, Williams D, Kelley M, Emanuele N. Ethanolinduced alterations in the posttranslational processing, but not secretion of luteinizing hormone-releasing hormone in vitro. Alcohol Clin Exp Res. 1996; 20(3):556-60.

152. Kim JH, Kim HJ, Noh HS, Roh GS, Kang SS, Cho GJ, et al. Suppression by ethanol of male reproductive activity. Brain Res. 2003;989(1):91-8.

153. Salonen I, Huhtaniemi I. Effects of chronic ethanol diet on pituitary-testicular function of the rat. Biol Reprod. 1990;42(1):55-62.

154. Zhu Q, Van Thiel DH, Gavaler JS. Effects of ethanol on rat Sertoli cell function: studies in vitro and in vivo. Alcohol Clin Exp Res. 1997;21(8):1409-17.

155. Zhu Q, Meisinger J, Emanuele NV, Emanuele MA, LaPaglia N, Thiel DH. Ethanol exposure enhances apoptosis within the testes. Alcohol Clin Exp Res. 2000;24(10):1550-6.

156. Pajarinen J, Karhunen PJ, Savolainen V, Lalu K, Penttilä A, Laippala P. Moderate alcohol consumption and disorders of human spermatogenesis. Alcohol Clin Exp Res. 1996;20(2):332-7.

157. Subiran N, Casis L, Irazusta J. Regulation of male fertility by the opioid system. Mol Med. 2011;17(7-8):846-53.

158. Brown $\Pi$, Wisniewski $A B$, Gonadal DAS. Adrenal abnormalities in drug users: cause or consequence of drug use behavior and poor health outcomes. Am J Infect Dis. 2006;2(3):130-5.

159. Sarafian TA, Magallanes JAM, Shau H, Tashkin D, Roth MD. Oxidative stress produced by marijuana smoke: an adverse effect enhanced by cannabinoids. Am J Respir Cell Mol Biol. 1999;20(6):1286-93.

160. Kim HR, Son BH, Lee SY, Chung KH, Oh SM. The role of p53 in marijuana smoke condensates-induced genotoxicity and apoptosis. Environ Health Toxicol. 2012;27:e2012017.

161. Faux SP, Tai T, Thorne D, Xu Y, Breheny D, Gaca M. The role of oxidative stress in the biological responses of lung epithelial cells to cigarette smoke. Biomarkers. 2009;1:90-6.

162. Abs R, Verhelst J, Maeyaert J, Van Buyten J-P, Opsomer F, Adriaensen H, et al. Endocrine consequences of long-term intrathecal administration of opioids. J Clin Endocrinol Metab. 2000;85(6):2215-22.

163. Daniell HW. Hypogonadism in men consuming sustained-action oral opioids. J Pain. 2002;3(5):377-84.
164. Fronczak CM, Kim ED, Barqawi $A B$. The insults of illicit drug use on male fertility. J Androl. 2012;33(4):515-28.

165. Park B, McPartland JM, Glass M. Cannabis, cannabinoids and reproduction. Prostaglandins Leukot Essent Fatty Acids. 2004;70(2):189-97.

166. Patra P, Wadsworth R. Quantitative evaluation of spermatogenesis in mice following chronic exposure to cannabinoids. Andrologia. 1991;23(2):151-6.

167. Heesch CM, Negus BH, Bost JE, Keffer JH, Snyder RW 2nd, Eichhorn EJ. Effects of cocaine on anterior pituitary and gonadal hormones. J Pharmacol Exp Ther. 1996;278(3):1195-200

168. Meri ZB, Irshid IB, Migdadi M, Irshid AB, Mhanna SA. Does cigarette smoking affect seminal fluid parameters? A comparative study. Oman Med J. 2013; 28(1):12-6.

169. Sheynkin Y, Gioia K. Environmental and lifestyle considerations for the infertile male. AUA Update Ser. 2013;32(4):30-8.

170. Tostes RC, Carneiro FS, Lee AJ, Giachini FR, Leite R, Osawa Y, et al. Cigarette smoking and erectile dysfunction: focus on NO bioavailability and ROS generation. J Sex Med. 2008;5(6):1284-95.

171. Halmenschlager G, Rossetto S, Lara GM, Rhoden EL. Endocrinology: evaluation of the effects of cigarette smoking on testosterone levels in adult men. J Sex Med. 2009;6(6):1763-72.

172. Shiels MS, Rohrmann S, Menke A, Selvin E, Crespo CJ, Rifai N, et al. Association of cigarette smoking, alcohol consumption, and physical activity with sex steroid hormone levels in US men. Cancer Causes Control. 2009; 20(6):877-86

173. Trummer $\mathrm{H}$, Habermann $\mathrm{H}$, Haas J, Pummer K. The impact of cigarette smoking on human semen parameters and hormones. Hum Reprod. 2002; 17(6):1554-9.

174. Kapoor D, Jones TH. Smoking and hormones in health and endocrine disorders. Eur J Endocrinol. 2005;152(4):491-9.

175. Neri M, Bello S, Bonsignore A, Cantatore S, Riezzo I, Turillazzi E, et al. Anabolic androgenic steroids abuse and liver toxicity. Mini Rev Med Chemist. 2011;11(5):430-7.

176. Buchanan JF, Davis LJ. Drug-induced infertility. Drug Intell Clin Pharm. 1984; 18(2):122-32.

177. de Souza GL, Hallak J. Anabolic steroids and male infertility: a comprehensive review. BJU Int. 2011;108(11):1860-5.

178. El Osta R, Almont T, Diligent C, Hubert N, Eschwege P, Hubert J. Anabolic steroids abuse and male infertility. Basic Clin Androl. 2016;26:1-8.

179. Foster ZJ, Housner JA. Anabolic-androgenic steroids and testosterone precursors: ergogenic aids and sport. Curr Sports Med Rep. 2004;3(4):234-41.

180. Fujii J, luchi Y, Matsuki S, Ishii T. Cooperative function of antioxidant and redox systems against oxidative stress in male reproductive tissues. Asian J Androl. 2003;5(3):231-42

181. Allen JA, Shankara T, Janus P, Buck S, Diemer T, Held Hales K, et al. Energized, polarized, and actively respiring mitochondria are required for acute Leydig cell steroidogenesis. Endocrinology. 2006;147(8):3924-35.

182. Chen H, Zhou L, Lin C-Y, Beattie MC, Liu J, Zirkin BR. Effect of glutathione redox state on Leydig cell susceptibility to acute oxidative stress. Mol Cell Endocrinol. 2010;323(2):147-54.

183. Veldhuis JD. Recent insights into neuroendocrine mechanisms of aging of the human male hypothalamic-pituitary-gonadal Axis. J Androl. 1999;20(1):1-18.

184. Diemer T, Allen JA, Hales KH, Hales DB. Reactive oxygen disrupts mitochondria in MA-10 tumor Leydig cells and inhibits steroidogenic acute regulatory (StAR) protein and steroidogenesis. Endocrinology. 2003;144(7):2882-91.

185. Koksal I, Usta M, Orhan I, Abbasoglu S, Kadioglu A. Potential role of reactive oxygen species on testicular pathology associated with infertility. Asian J Androl. 2003;5(2):95-100.

186. Hanukoglu I. Antioxidant protective mechanisms against reactive oxygen species (ROS) generated by mitochondrial P450 systems in steroidogenic cells. Drug Metab Rev. 2006;38(1-2):171-96.

187. Peltola V, Huhtaniemi I, Metsa-Ketela T, Ahotupa M. Induction of lipid peroxidation during steroidogenesis in the rat testis. Endocrinology. 1996; 137(1):105-12.

188. Perheentupa A, De Jong F, Huhtaniemi I. Biphasic effect of exogenous testosterone on follicle-stimulating hormone gene expression and synthesis in the male rat. Mol Cell Endocrinol. 1993:93(2):135-41.

189. Perheentupa A, Huhtaniemi I. Gonadotropin gene expression and secretion in gonadotropin-releasing hormone antagonist-treated male rats: effect of sex steroid replacement. Endocrinology. 1990;126(6):3204-9.

190. Aitken RJ, Roman SD. Antioxidant systems and oxidative stress in the testes. Oxidative Med Cell Longev. 2008;1(1):15-24. 
191. Chigurupati S, Son TG, Hyun D-H, Lathia JD, Mughal MR, Savell J, et al. Lifelong running reduces oxidative stress and degenerative changes in the testes of mice. J Endocrinol. 2008;199(2):333-41.

192. Loveland KL, Klein B, Pueschl D, Indumathy S, Bergmann M, Loveland BE, et al. Cytokines in male fertility and reproductive pathologies: Immunoregulation and beyond. Front Endocrinol. 2017:8:1-16.

193. Maegawa M, Kamada M, Irahara M, Yamamoto S, Yoshikawa S, Kasai Y, et al. A repertoire of cytokines in human seminal plasma. J Reprod Immunol. 2002;54(1-2):33-42.

194. Joki-Korpela P, Sahrakorpi N, Halttunen M, Surcel HM, Paavonen J, Tiitinen A. The role of Chlamydia trachomatis infection in male infertility. Fertil Steril. 2009;91(4 Suppl):1448-50.

195. Ochsendorf F. Infections in the male genital tract and reactive oxygen species. Hum Reprod Update. 1999;5(5):399-420.

196. Dejucq N, Jegou B. Viruses in the mammalian male genital tract and their effects on the reproductive system. Microbiol Mol Biol Rev. 2001;65(2):208-31.

197. Aiman J, Brenner PF, MacDonald PC. Androgen and estrogen production in elderly men with gynecomastia and testicular atrophy after mumps orchitis. J Clin Endocrinol Metab. 1980;50(2):380-6.

198. Adamopoulos DA, Lawrence DM, Vassilopoulos P, Contoyiannis PA, Swyer Gl. Pituitary-testicular interrelationships in mumps orchitis and other viral infections. Br Med J. 1978;1(6121):1177-80

199. Dimitrakov J, Joffe HV, Soldin SJ, Bolus R, Buffington CT, Nickel JC. Adrenocortical hormone abnormalities in men with chronic prostatitis/ chronic pelvic pain syndrome. Urology. 2008;71(2):261-6.

200. Lane TM, Hines J. The management of mumps orchitis. BJU Int. 2006;97(1):1-2.

201. Zirkin BR, Chen H. Regulation of Leydig cell steroidogenic function during aging. Biol Reprod. 2000;63(4):977-81.

202. Turner TT, Bang HJ, Lysiak JJ. Experimental testicular torsion: reperfusion blood flow and subsequent testicular venous plasma testosterone concentrations. Urology. 2005;65(2):390-4.

203. Luo L, Chen H, Trush MA, Show MD, Anway MD, Zirkin BR. Aging and the brown Norway rat leydig cell antioxidant defense system. J Androl. 2006; 27(2):240-7.

204. Aitken RJ, Baker MA, Sawyer D. Oxidative stress in the male germ line and its role in the aetiology of male infertility and genetic disease. Reprod BioMed Online. 2003;7(1):65-70

205. Agarwal A, Said TM. Role of sperm chromatin abnormalities and DNA damage in male infertility. Hum Reprod Update. 2003;9(4):331-45.

206. Meucci E, Milardi D, Mordente A, Martorana GE, Giacchi E, De Marinis L, et al. Total antioxidant capacity in patients with varicoceles. Fertil Steril. 2003;79:1577-83.

207. Mancini A, Leone E, Festa R, Grande G, Silvestrini A, Marinis L, et al. Effects of testosterone on antioxidant systems in male secondary hypogonadism. J Androl. 2008;29(6):622-9.

208. Chainy G, Samantaray S, Samanta L. Testosterone-induced changes in testicular antioxidant system. Andrologia. 1997;29(6):343-9.

209. Shang X, Huang Y, Ye Z, Yu X, Gu W. Protection of melatonin against damage of sperm mitochondrial function induced by reactive oxygen species. Zhonghua Nan Ke Xue. 2004;10(8):604-7.

210. Lakpour N, Mahfouz RZ, Akhondi MM, Agarwal A, Kharrazi H, Zeraati H, et al. Relationship of seminal plasma antioxidants and serum male hormones with sperm chromatin status in male factor infertility. Syst Biol Reprod Med. 2012;58(5):236-44.

211. Oluboyo A, Adijeh R, Onyenekwe C, Oluboyo B, Mbaeri T, Odiegwu C, et al. Relationship between serum levels of testosterone, zinc and selenium in infertile males attending fertility clinic in Nnewi, south East Nigeria. Afr J Med Med Sci. 2012;41:51-4

212. Safarinejad MR. Efficacy of coenzyme Q10 on semen parameters, sperm function and reproductive hormones in infertile men. J Urol. 2009;182(1): 237-48.

213. Richthoff J, Spano M, Giwercman Y, Frohm B, Jepson K, Malm J, et al. The impact of testicular and accessory sex gland function on sperm chromatin integrity as assessed by the sperm chromatin structure assay (SCSA). Hum Reprod. 2002;17(12):3162-9.

214. Meeker JD, Singh NP, Hauser R. Serum concentrations of estradiol and free T4 are inversely correlated with sperm DNA damage in men from an infertility clinic. J Androl. 2008;29(4):379-88.

215. Dobrzyńska MM, Baumgartner A, Anderson D. Antioxidants modulate thyroid hormone-and noradrenaline-induced DNA damage in human sperm. Mutagenesis. 2004;19(4):325-30.
216. Palomba S, Falbo A, Espinola S, Rocca M, Capasso S, Cappiello F, et al. Effects of highly purified follicle-stimulating hormone on sperm DNA damage in men with male idiopathic subfertility: a pilot study. J Endocrinol Investig. 2011:34(10):747-52.

217. Colacurci N, Monti MG, Fornaro F, Izzo G, Izzo P, Trotta C, et al. Recombinant human FSH reduces sperm DNA fragmentation in men with idiopathic oligoasthenoteratozoospermia. J Androl. 2012;33(4):588-93.

218. Tesarik J, Martinez F, Rienzi L, lacobelli M, Ubaldi F, Mendoza C, et al. In-vitro effects of FSH and testosterone withdrawal on caspase activation and DNA fragmentation in different cell types of human seminiferous epithelium. Hum Reprod. 2002;17(7):1811-9.

219. Nematollahi-Mahani SN, Azizollahi GH, Baneshi MR, Safari Z, Azizollahi S. Effect of folic acid and zinc sulphate on endocrine parameters and seminal antioxidant level after varicocelectomy. Andrologia. 2014;46(3):240-5.

220. Manna PR, Tena-Sempere M, Huhtaniemi IT. Molecular mechanisms of thyroid hormone-stimulated steroidogenesis in mouse Leydig tumor cells involvement of the steroidogenic acute regulatory (StAR) protein. J Biol Chem. 1999:274(9):5909-18.

\section{Ready to submit your research? Choose BMC and benefit from:}

- fast, convenient online submission

- thorough peer review by experienced researchers in your field

- rapid publication on acceptance

- support for research data, including large and complex data types

- gold Open Access which fosters wider collaboration and increased citations

- maximum visibility for your research: over $100 \mathrm{M}$ website views per year

At BMC, research is always in progress.

Learn more biomedcentral.com/submissions 